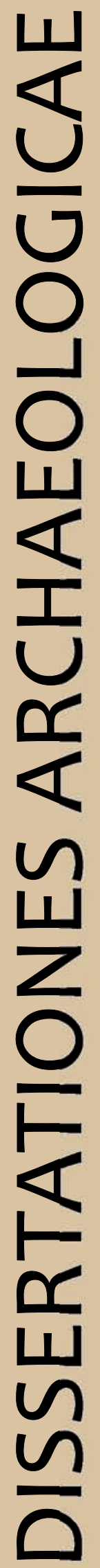

ex Instituto Archaeologico Universitatis de Rolando Eötvös nominatae

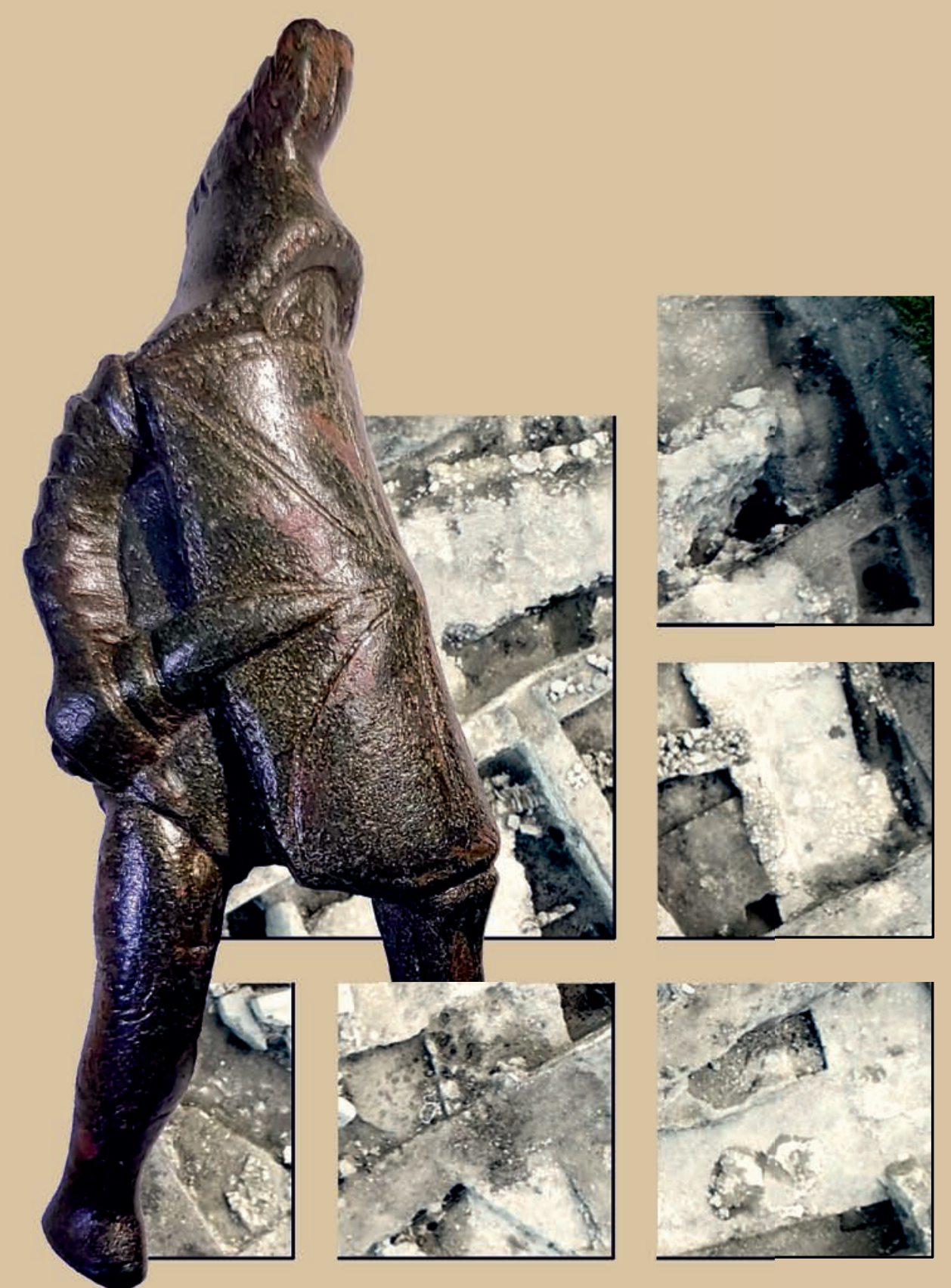

$$
\text { Ser. 3. No. 7. } 2019
$$




\section{Dissertationes Archaeologicae ex Instituto Archaeologico}

Universitatis de Rolando Eötvös nominatae Ser. 3. No. 7.

Budapest 2019 
Dissertationes Archaeologicae ex Instituto Archaeologico Universitatis de Rolando Eötvös nominatae

Ser. 3. No. 7.

Editor-in-chief:

DÁvid BARTUS

Editorial board:

LÁsZló BARTOSIEWICZ

LÁSZLÓ BORHY

ZOLTÁN CZAJLIK

IsTVÁN FELD

GÁBOR KALLA

PÁL RACZKY

MikLÓs SzABÓ

TivadAR VidA

Technical editor:

GÁBOR VÁCZI

Proofreading:

SZILVIA BARTUS-SZÖLLősI

ZsóFIA KondÉ

Aviable online at http://dissarch.elte.hu

Contact: dissarch@btk.elte.hu

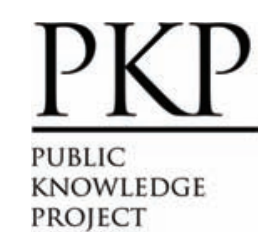

๑ ELTE Eötvös Loránd University, Institute of Archaeological Sciences

Layout and cover design: Gábor Váczi

Budapest 2019 


\section{CONTENTs}

\section{ARticles}

János Gábor TARBAY

The Casting Mould and the Wetland Find - New Data on the Late Bronze Age

Peschiera Daggers

Máté MeRvel

Late Bronze Age stamp-seals with negative impressions of seeds from Eastern Hungary

János Gábor TARBAY

Melted Swords and Broken Metal Vessels - A Late Bronze Age Assemblage

from Tatabánya-Bánhida and the Selection of Melted Bronzes

Ágnes ScHNEIDER

Multivariate Statistical Analysis of Archaeological Contexts: the case study

of the Early La Tène Cemetery of Szentlörinc, Hungary

Csilla SÁRÓ - Gábor LASSÁNYI

Bow-tie shaped fibulae from the cemetery of Budapest/Aquincum-Graphisoft Park

Dávid BARTus

Roman bronze gladiators - A new figurine of a murmillo from Brigetio

Kata DÉvAI

Re-Used Glass Fragments from Intercisa

Bence Simon

Rural Society, Agriculture and Settlement Territory in the Roman, Medieval and Modern Period Pilis Landscape

Rita RAKONCZAY

„Habaner“ Ofenkacheln auf der Burg Čabrad”

\section{FIELD REPORT}

Bence Simon - Anita Benes - Szilvia Joháczi - Ferenc BARnA

New excavation of the Roman Age settlement at Budapest dist. XVII, Péceli út (15127) site 


\section{Thesis Abstracts}

Kata SzILÁGYi

Die Silexproduktion im Kontext der Südosttransdanubischen Gruppe

der spätneolithischen Lengyel-Kultur

Norbert FARAGÓ

Complex, household-based analysis of the stone tools of Polgár-Csőszhalom

János Gábor TARBAY

Type Gyermely Hoards and Their Dating - A Supplemented Thesis Abstract

Zoltán Havas

The brick architecture of the governor's palace in Aquincum

Szabina Merva

'...circa Danubium...' from the Late Avar Age until the Early Árpádian Age-

$8^{\text {th }}-11^{\text {th }}$-Century Settlements in the Region of the Central Part of the Hungarian

Little Plain and the Danube Bend

Szabolcs Balázs NAGY

Noble Residences in the $15^{\text {th }}$ century Hungarian Kingdom - The Castles of Várpalota,

Ujlak and Kisnána in the Light of Architectural Prestige Representation

Ágnes KollátH

Tipology and Chronology of the early modern pottery in Buda 


\title{
The brick architecture of the governor's palace in Aquincum
}

Zoltán Havas

Archäologiebüro Dr. Woidich GmbH, Harburg (Schwaben)

zoltan.havas@gmail.com

\begin{abstract}
Abstract of PhD thesis submitted in 2019 to the Archaeology Doctoral Programme, Doctoral School of History, Eötvös Loránd University, Budapest under the supervision of Dénes Gabler
\end{abstract}

\section{The aims of the dissertation and its role in connected research}

The research of the praetoria of the Principate, the building complexes that served as the residence and offices of the heads of provincial administration, has become a noted subject of Roman provincial archaeology with a considerable international bibliography. Given that only a few (altogether five) of these, more or less excavated, archaeologically identified sites are known to research, the significant international interest concerning the governor's palace excavated on Hajógyári Island in Óbuda is understandable. The dissertation entitled 'The brick architecture of the governor's palace in Aquincum' wishes to contribute to the scientific study of the site. Given, however, the scope of the topic and the limited progress made by previous research, the dissertation cannot serve as a comprehensive monograph on the site.

The Hajógyári Island site has been known for a long time, its research history and fate closely bound with the history of shipbuilding in Obuda between 1835 and 1990. The most significant excavations on the site took place between 1941 and 1956. These were followed by only a few modern excavations in the 1990s under the leadership of Katalin Kérdő. Unfortunately, during the long period (1956-1991) when the detailed publication of the governor's palace was not accomplished, neither was the complete presentation of the various excavated contexts, building parts, stratigraphic units or the periodisation based on finds and startigraphic observations. In the meantime, the documentation of the most significant excavations became disorganised and incomplete.

The documentation of the excavations conducted between 1941 and 1956 received rightful criticism not only for their eventual incompleteness. In some respects, the documentation did not even meet the standards of its own time. Undoubtedly, a significant part of the shortcomings was due to the circumstances of the excavation.

These factors had blurred the connection between the finds and the find spot to such an extent that studying the analysed finds in context became a challenge in itself.

I, therefore, sought to work on areas and sub-topics that not only complement and give the background to previous analyses of the material, but also provide a stable foundation for other studies and publications of the site. 
It was clear from the start that a great emphasis had to be placed on the discussion of research history. The site of the governor's palace became known early on, in the 1830s, and the over 100 years until 1941 saw the discovery of spectacular and significant finds as well as the excavation of important parts of the main building. In spite of their significance, however, the results of these early forays were mostly forgotten; the precise provenience of finds traditionally connected with the palace too was uncertain.

In the absence of a monograph on the governor's palace, the review of relevant publications and determining the precise state of research were also important tasks.

Concerning the bricks, previously I did not search for their potential place(s) of production; that is to say, to connect to actual locations the various 'workshops' identified in the abstract based on the finds. Here I attempted to do so in the research history section on the one hand and as part of the topographical analysis on the other.

Concerning the analysis of the material, in this work phase, only limited progress was possible, which focused on the still extant bricks from the pre-1941 period. To a lesser extent it also complemented the analysis of the 1941-1998 material. To allow the subject to be studied in context, it seemed necessary to redo in a new form all the previous analyses of the material that was indispensible for interpreting the extended catalogue.

The topographical position of the governor's palace, its special location on an island of a border river, is a key subject that has inspired researchers and prompted them to take positions on the matter since the significance of the site was first identified. This has led to numerous concepts and interpretations that partly build on and partly criticise each other. In light of further work on the site, it seemed important to revisit the question, and - as far as possible - place it on realistic, reassuring foundations as well as record the open topographical questions.

We were also left with an equally significant uncertainty concerning the periodisation of the site, which precludes any and all further analysis and evaluation of the material. The preliminary reports at the end of the excavations, too, published clear alternatives - though containing internal contradictions - for the building's construction periods; a debate then followed on the issue between János Szilágyi and István Wellner. The fact that in 2014 Felix Schäfer still saw it possible to revise the construction periods of the Aquincum palace based on only the publications accessible to him shows just how fluid the state of the issue still is. For all future steps, it was of utmost importance to revive and re-evaluate the documentation of the excavations between 1941 and 1956 and, based on the possible stratigraphical observations, to set up a new periodisation.

The previous analysis of the material did not cover how the bricks studied were used at the governor's palace. Although the documentation was only suitable for this to a limited extent, the collection of the extractable data was nonetheless important. After all, not only can it provide details on the palace complex's architecture and the building techniques, in certain cases it can help in describing and identifying the construction periods.

All the aforementioned strands of research and subtopics led to realisations that significantly altered the previously-held image of the governor's palace, which was also presented in an architectural reconstruction. Therefore, it became necessary to revise the architectural reconstruction as well. 


\section{The methodology and structure of the dissertation}

In line with the aforementioned aims, the first larger unit (Chapter 2) covers research history. It begins with a chronicle-style review, which presents the growing body of information and finds as well as the various excavations connected to the site in chronological order. All finds and excavations are mentioned here which previous research has connected - correctly or incorrectly - to the site of the governor's palace. Presenting the evaluation and arguments behind the analysis here was especially necessary in the case of $19^{\text {th }}$ century data.

The next section of research history covers the state of the analysis and publication of the materials at the beginning of the doctoral research. In addition to the literature concerning the site in general, this section also presents the state of research separately for the various material groups.

The brief overview of brick production in Aquincum, too, was included in the research history section. The reason for this was that the dissertation did not seek to provide deeper analysis on the subject of Aquincum brick production, especially since the known brick workshops, production sites had little to no connection with the bricks used on the site covered by the doctoral research. Since this connection was doubtful from the start, the sub-chapter focused on examining the question whether any of the known workshops could have produced the bricks used at the governor's palace.

Chapter 3 on the analysis of the material reviews the main characteristics and indicators of the governor's palace's material, the state of the research, and the methodology. This chapter overlaps considerably with my 2005 degree thesis, as I did not change the angles of analysis or the methodology, but applied them here consistently.

Chapter 4 covers all the research on the topography of the site. The starting point was to consider the factors that may have influenced the choice of location for the palace complex.

The nature and manifestation of the relationship between the governor's palace and the Military Town had to be studied separately, especially with regard to the north-eastern quarter of the canabae, which is traditionally connected with the palace.

A number of new observations could be made concerning the immediate surroundings of the palace, primarily regarding the surrounding landscape and the possible related topographical features we expect to find in the vicinity.

Lastly, treated in a separate section, were the questions regarding the nature of the river crossing point suspected just south of the palace and the dating of the known bridge remains, which naturally could only be studied together with the connected fort on the left bank of the river.

The first section of Chapter 5 on evaluation covers the work process, methods and results of the new stratigraphic evaluation and periodisation.

The following section summarises the data on brick production, manufacturing techniques and individual workshops, based completely on the results of my 2005 degree thesis.

The uses of ceramic building materials and the applicable observations on building techniques at the site in question are collected in section 5.3, grouped according to the area of use and position in building structure. 
Lastly, the revision of the architectural reconstruction by Gyula Hajnóczy and Tamás Mező is covered in section 5.4. Here, I reviewed the development and methodology of the reconstruction, and described in detail eight aspects, features that need to be altered. The new reconstruction taking shape based on this revision is the shared work of Zsolt Vasáros and myself; Gábor Nagy, too, participated in the graphic visualisation of the model.

The bibliography is followed by the documentation that served as the background of the periodisation work. The catalogue of objects is an extended and updated version of the catalogue created during the 2005 analysis of the material. Similarly, the 2005 tables present authentically the catalogued material types. As comparison and illustration, I extended the tables with further tables presenting the brick stamp types of the Bécsi Road workshop.

\section{The main results of the dissertation}

The study of the research history resulted in a chronological database referencing all extant publications, repository and archive documents, catalogue entries and finds. This is already useful in and of itself for any future research on the site. The analysis of the sources at our disposal also enriched our understanding with numerous new details. The closer contexts of several known finds discovered in the $19^{\text {th }}$ century could be identified. For instance, the identification of the mosaic of Hall no. 1, and the fact that it was heated, along with the original location of the engraved inscription published by Flóris Rómer also lead to an improved understanding of the development and use of the palace complex. Some of the documents used were well-known, but the circumstances of their origins were unclear; in the case of drawings, the depicted features had not been identified earlier. In other cases, completely new, previously unused sources could also be included.

Concerning the $19^{\text {th }}$ century finds there were not only positive, but also equally significant negative results. Several iconic finds previously connected with the palace material, or identified by previous research as being part of it were proven to be unrelated to our site, as - though mostly from the vicinity - they were actually found elsewhere. These include numerous sculptures (bronze figurines, fragments of larger statues), a bronze balsamarium, krater(s) depicting a thiasos, as well as a number of inscribed stones.

It was surprising to be able to discover forgotten episodes beyond the $19^{\text {th }}$ century. For instance, a previously unknown piece of information from 1969 came up and contributed an important detail to the summary ground plan.

It was also important to summarise the current state of the analysis of the finds and the separate partial results for future research.

The purpose of reviewing our knowledge of Aquincum brick production was precisely to ascertain whether there may be a connection between the bricks of the governor's palace and the currently known production sites. For now, the answer is negative. The stamp types that provide a quite unique character to the material of the palace appear hardly or not at all among the materials of the known workshops.

Most of the questions studied during topographical researches pertain to the whole interpretation of the site. These include for instance the question of choosing the site of the palace. I consider the main reasons to be the excellent and independent transport and infrastructure 
conditions of the site. In comparison, the following seem to be secondary considerations: political show of force; pleasant landscape; need for an exposed, yet separate location.

On closer inspection of the connection between the governor's palace and the Military Town, it appears that the palace complex adjoins the town quarter as a separate entity; it is neither part of the dense urban fabric, nor does it stand alone as a Solitärbau. The northern, north-eastern quarter of the canabae was likely more colourful and diverse than previously thought. We need to express our ideas and expectations concerning the area more leniently. The relationship between the palace and the town quarter appears less direct and does not reach the kind of depth that could, for instance, also be illustrated with the brick material.

Concerning the connections and the quarter's diverse nature, we also need to take into account the currently unknown but presumed topographical features like the castra singularium and the site where the bricks of the palace were produced. Both are to be located in the north-eastern quarter or in its immediate vicinity to the north.

All works analysing the topographical position of the palace mention two aspects of Aquincum topography, the connection of which to the governor's palace might at first seem evident. In the case of the fort excavated at the mouth of the Rákos Stream and the bridge connecting it to the legionary fortress, I went back to the primary sources from the time of the excavations and tried to find an archaeological reason for dating these as contemporaries of the palace. Doubts concerning the permanent nature and the structure of the bridge had been raised already prior to and independently of this investigation.

With respect to the fort, I currently see no detail that would justify a date prior to the late Roman period.

With respect to the bridge, I consider those practical and technical points justified, which would make it unlikely that the whole length of the bridge was a permanent wood or stone construction. Its dating, too, is uncertain, but - provided that the stone remains found and secondarily used on Fürdő Island belonged to this structure - a date before the $4^{\text {th }}$ century is rather unlikely. There certainly would have been a river crossing in the area during the existence of the palace. This could have been a ferry, or a pontoon bridge, possibly with some permanent sections.

The stratigraphical re-evaluation of the 1941-1956 excavations' documentation made it possible to create a new periodisation that seems to be better-grounded than previous ones. The creation of the new periodisation and the work on the documentations leading to it are one of the most important results of my dissertation. The five identified and, to a certain extent, comprehensively describable, construction periods define unambiguously only the outline, the main periods of construction on the site. In addition to searching for and then systematising extant documentation and selecting the sources suitable for stratigraphical analysis, it was also necessary to conduct a source-critical analysis to be able to compile an excavation documentation in the modern sense.

The stratigraphical connections identified during the re-documentation proved to be sufficient for defining the most important construction periods of the main building of the palace. The first period was a construction that was carefully torn down or never fully completed, differing in both layout and structure from the later building complex. There is no proof for 
its use as the governor's palace. The second period contains multiple phases during the $2^{\text {nd }}$ century, probably from 119 AD until the start of the third period of construction. During the second period, the basic image and layout of the main building as well as the function of the wings and other parts were established. The third period of construction was a relatively sudden, comprehensive work most likely between AD 211 and 222. This period saw the development primarily of the features that served official purposes and the comfort of residents. This was followed by at least one more comprehensive rebuilding following an original concept during the $3^{\text {rd }}$ century (fourth period), which primarily saw the increase in the defensive and economic functions, but in certain areas organically continued the direction of previous constructions. After the fourth period came smaller constructions without a clearly-discernible purpose and character. These may indicate a longer period of use (until the end of the century).

There was a natural interplay between the periodisation work and the examination of the bricks. Certain, closely dateable brick stamps were fundamental sources for confirming and systematising startigraphical observations. In other cases bricks stamps of previously uncertain dating could be connected with a construction period, and thus to a more precise time frame.

The basic assumption behind collecting the use of bricks and the applicable architectural solutions was that such a collection could shed light on the use and functioning of the building, and provide meaningful assistance with periodisation and the architectural reconstruction. In the end, it also allows us to recognise and appreciate the palace complex's real architectural quality and standard compared to the architecture of the age.

In spite of the limited number of discoverable details, certain conclusions could be ventured in the latter regard as well. In my opinion, the main difference between 'regular' Aquincum buildings and the governor's palace is mostly one of quantity. In the local context, the number of bricks used is conspicuously high, which indicates a relatively greater supply and fastidiousness. The palace also featured the most complete and multi-faceted set of local brick architecture, utilising all locally-known and available possibilities. The palace, therefore, reaches the pinnacle of local architecture, but seeks to achieve nothing more. Perhaps its builders did not expect anything more either.

The revision of the architectural reconstruction, despite its excerpted nature, in a sense summarises but also takes further the observations made during the analysis of research history, periodisation, topography, and construction technology, which substantively alter our image of the palace complex. I also sought to present the methodology and sources of the previous reconstruction as well as the background of its mistakes and shortcomings.

Nowadays we see the morphology of the landscape around the palace and the wider topographical environment, too, differently. This means significant differences especially concerning the main facade and the area in front of it. Based on our better understanding of $19^{\text {th }}$ century data we must discard the idea of staircases in the corner towers. This, however, gives us a new angle for interpreting the halls of the eastern, official wing.

We cannot say conclusively whether or not the palace had two storeys, nonetheless we must point out that there is still no substantive evidence for an upper floor.

The previous reconstruction handled the question of open and closed space rather loosely. Based on the excavation documentation, this, by all means, had to be revised, making the 
reconstruction of the building's mass and roof as well as the function of the various areas more realistic. This also applies to the functional and physical division of the large inner court.

The western wing of the main building remains an open question; the data at our disposal is not sufficient for an answer. Nonetheless, certain basic outlines and minimum requirements for possible solutions can be defined.

Room 48 is a classic example of how a series of mistakes, misunderstandings and being unaware of key data can make the reconstruction so far off the mark. The fountain, which appeared on previous drawings and the model, should, we now believe, be replaced with an aedicula.

Due to its partially-excavated state, the so-called Building 2, linked directly to the main building from the south, is also still an open question. By supplementing the incompletelypublished ground plans based on the documentation, and using architectural analogies, we can gain a better image of the real mass, shape and layout of the building. With questions like this, reconstruction goes beyond simply representing the results of research: it becomes a tool of research of its own.

\section{Publications of the author on the subject}

HAVAs, Z. 2007:Jelölések római téglákon - egy értelmezési kísérlet. (Handmarken auf römischen Ziegeln - ein Deutungsversuch). In: Bíró Sz. (Ed.): FiRKáK I. Fiatal Római Koros Kutatók I. Konferenciakötete. Győr, 173-184.

Havas, Z. 2007: 52. Budapest III., Hajógyári-sziget. Kisfaludy, J. (szerk.): Régészeti kutatások Magyarországon 2006 (Archaeological Investigation in Hungary 2006). Budapest, 171.

HAvAs, Z. 2008: Szondázó kutatások az óbudai Hajógyári-szigeten (Test excavations on Óbuda (Dockyard) Island) Aqincumi Füzetek 14, 24-39.

Havas, Z. 2008: A cohors VII Breucorum régi-új Maximiniana jelzős bélyegü téglái. (Die Stempelziegel mit dem alten-neuen Maximiniana-Ehrentitel der Cohors VII Breucorum) Archaeologiai Értesitó 133, 129-132.

Havas, Z. 2009: 53. Budapest, III. Hajógyári-sziget. Kisfaludy, J. (szerk.): Régészeti kutatások Magyarországon 2008 (Archaeological Investigation in Hungary 2008). Budapest, 159-163.

Havas, Z. - TÉzer, Z. 2009: Feltárások az óbudai Hajógyári-szigeten 2008-ban (Excavations on the Dockyard Island in Óbuda in 2008). Aqincumi Füzetek 15, 30-43.

Havas, Z. 2009: Atilia Firma téglaműhelyének termékei Pannoniában. (Erzeugnisse der Ziegelwerkstatt des Atilia Firma in Pannonien). In: Bíró, Sz. (ed.): Ex officina... Studia in honorem Dénes Gabler. Győr, 205-223.

Havas, Z. - Тóтн A. 2010: Feltárások az óbudai Hajógyári-szigeten 2009-ben (Excavations on Dockyard Island in Óbuda in 2009). Aqincumi Füzetek 16, 68-85.

HAVAs, Z. 2010: Die römischen Ergebnisse einer mittelalterlichen Ausgrabung - römische Spolien auf der Schiffswerft-Insel (Hajógyári-Sziget). In: STIPANITs, U. - LÁNG, O. (eds): VindobonaAquincum: Herausforderungen und Ergebnisse in der Stadtarchäologie Wien, 3.-4. Dezember 2009. Aquincum Nostrum II/6. Budapest, 69-84.

HAVAs, Z. 2012: Egy középkoros ásatás római eredményei - másodlagos, többedleges lelőhelyű római kőfaragványok a Hajógyári-szigeten (Die römischen Ergebnisse einer mittelalterlichen Ausgrabung - römische Spolien auf der Schiffswerft-Insel [Hajógyári-Sziget]) In: Bíró, Sz. VÁmos, P. (eds): FiRKák II. Fiatal Római Koros Kutatók II. Konferenciakötete. Győr, 125-150. 
TóтH, O. - Sipos, Gy. - HAvAs, Z. 2014: TL/OSL kormeghatározás tesztelése római kori bélyeges téglákon (The testing of TL and OSL methods on archeologically accurately dated brick samples). Archeometriai Mühely XI/1, 13-26.

HAVAS, Z. 2014: New evidence of the role of geographic elements in settlement history (Data on the archeological topography of the Southern part of the Óbuda Nagy Island). In: H. KÉRDő, K. Schweitzer, F. (eds): Aquincum Ancient landscape - ancient town. Budapest, 136-139.

Havas, Z. 2014: Tituli Aquincenses 4. Bélyeges téglák, Bevezetés. Studia Epigraphica Pannonica 6, 45-50.

Viczián, I. - Havas, Z. - BALOGH, J. - SzeberéNYi, J. - Kis, É. 2014: Geomorfológiai adottságok és környezeti változások szerepe az emberi megtelepedés és területhasználat történetében az Óbudai-szigeten. In: KóRódi T. - SAnsumné MolnÁR J. - SiskÁNÉ Szilasi B. - Dobos E. (szerk.): VII. Magyar Földrajzi Konferencia kiadványa. Miskolc, 652-659.

Havas, Z. 2014: Amikor a lelőhely vész el, majd kerül újra elő. Kerek mozaik(ok) az aquincumi helytartói palotából. Ókor 2014/4, 84-90.

Viczián I. - Havas Z. - BAlogh J. - Szeberényi J. 2014: Az Óbudai-sziget geomorfológiája és környezettörténete In: FÜleKY, Gy. (ed.): A táj változásai a Kárpát-medencében. A vízgazdálkodás története a Kárpát-medencében. Baja, 87-92.

Viczián, I - Havas, Z - Szeberényi, J - BALOGH, J. 2015: Az Óbudai-sziget környezettörténete. In: Csabai Z. - Földi Zs. - Grüll T. - VéR Á. (szerk.): Ókonómia és ökológia: Tanulmányok az ókori gazdaságtörténet és történeti földrajz köréból. Pécs 2015, 327-344.

Havas, Z. 2016: Der Statthalterpalast von Aquincum - Forschungsstand 2015. In: BeszéDES, J. (ed.): Legionslager und canabae legionis in Paanonien. Internationale Archäologische Konferenz. 16-17. November, 2015. Aquincum Nostrum II/7. Budapest, 81-102.

VAsÁros, Zs. - Havas, Z. 2019: Revision of the architectural reconstruction of the Aquincum Governor's Palace. In: Havas, Z. (ed.): Authenticity and Experience - Governor's Palaces of the Roman Imperial Period and the Limes. Proceedings of the International Conference Budapest, 5-6. November 2018. Aquincum Nostrum II/8. Budapest, 77-95. 